\title{
Fábulas sem olhos: os roteiros não filmados na historiografia do cinema brasileiro
}

Pablo Gonçalo

Universidade de Brasília, Brasília, Distrito Federal, Brasil

\section{Resumo}

O ensaio propõe uma revisão historiográfica do cinema brasileiro a partir dos roteiros não filmados. Seguindo uma análise de roteiros não filmados de Mário Peixoto, Vítor Lima Barreto e Joaquim Pedro de Andrade, sugere-se captar estilos, projetos e intenções estéticas que anunciaram aspectos históricos não consolidados nos ciclos cinematográficos compreendidos por esses diretores. Os roteiros não filmados são analisados a partir de uma metodologia de uma arqueologia especulativa. Seja no cinema dos anos vinte, no projeto da Vera Cruz ou ainda nas relações entre o Cinema Novo e a Embrafilme, esse conjunto de roteiros revela imaginários estéticos potentes que nos permitem vislumbrar aspectos contracíclicos dos períodos cinematográficos que dialogaram e prenunciaram.

Palavras-chave:

Cinema Brasileiro. Historiografia.

Roteiros não filmados.

\section{Introdução}

Numa das suas assertivas mais célebres, Paulo Emílio Salles Gomes ressaltava como o cinema brasileiro estaria condenado a uma constante e insuperável condição de subdesenvolvimento. Ele referia-se sobretudo aos acontecimentos históricos dos cinemas periféricos, que seriam incompletos, com produções escassas e interrompidas. Na sua argumentação, esse "[...] cinema é incapaz de encontrar dentro de si próprio energias que lhe permitem escapar à condição de subdesenvolvimento" (GOMEs, 1996, p. 85). Desprovida de uma autorreferência tida como legítima, a história do cinema brasileiro tenderia, seguindo sua influente proposição, a ver suas constelações estéticas como distantes, ou teria no cinema estrangeiro suas principais referências.

Atualmente, o ensaio de Gomes (1996) já foi revisto e criticado por um importante grupo de historiadores (BERNARDET, 2004). Termos e conceitos como ciclos e subdesenvolvimento revelam-se mais circunscritos a uma agenda 
econômica e política dos anos setenta, e não apontam com precisão para outros acontecimentos culturais caros aos filmes e períodos analisados por Gomes. Embora compartilhemos dessas críticas, gostaríamos de sugerir, nestas linhas, um possível adensamento das ideias propostas pelo crítico paulista; ou, por outro viés, a abertura de um flanco paralelo que permitisse tanto levar adiante como desconfiar do alcance das suas proposições.

Mais do que pensar nos ciclos como acontecimentos interrompidos, pretendemos alinhavar intenções, rastros, anseios e mesmo imaginações não engendradas pelos pêndulos (e olhos) da história. Mais do que acompanhar, portanto, apenas os filmes realizados e lançados, ensaiaremos jogar algumas luzes em intenções cinematográficas consistentes que não migraram às telas. Não teríamos na negatividade, no descarte e no abandono de uma gama de projetos incompletos índices 2 de outros cinemas (ainda) possíveis? Não haveria nessa fenda negativa da história uma arqueologia especulativa (GONÇALO, 2018) que coligaria imaginários e tradições sugeridas de cineastas do passado com os olhares do nosso tempo atual?

Esse novelo de perguntas aponta para uma possível contribuição dos roteiros não filmados à historiografia do cinema brasileiro. Numa acepção "contracíclica” do cinema brasileiro, os roteiros não filmados carregariam apreensões históricas e estéticas pertinentes. Nossa intenção, nas próximas páginas, é de compartilhar um conjunto de roteiros não filmados que seriam reveladores dessas facetas arqueológicas, contracíclicas e especulativas de um cinema brasileiro que não se consolidou nas telas. Embora sejam cinematografias restritas ao papel, decidimos investigar roteiros de três conjuntos, autores, em períodos consistentes e representativos de diferentes períodos do cinema brasileiro. Seguindo uma ordem cronológica, compartilharemos, em primeiro lugar, uma análise do roteiro O Sono Sobre a Areia, de Mário Peixoto. Esse filme é o segundo da carreira de Mário Peixoto, cuja gravação ocorreu pouco tempo após o lançamento de Limite (1931). Cotejado com os demais roteiros de Peixoto, O Sono Sobre a Areia ilumina aspectos estéticos que quedaram incompletos num complexo universo que abrange o estilo, a carreira, as ambições (e frustrações) despontadas pelo próprio Peixoto.

O segundo cineasta é Vítor Lima Barreto, cuja trajetória foi intimamente atrelada ao projeto industrial da Vera Cruz. Neste ensaio, analisaremos duas histórias que permitem vislumbrar as suas ambições estéticas e a sua aposta no roteiro como um elemento de transmissão geracional e, por fim, de cunho literário. O primeiro projeto é O Sertanejo, roteiro que 
se seguiria ao sucesso de O Cangaceiro (1953). Até onde se sabe, esse roteiro seria a primeira adaptação de Os Sertões, de Euclides da Cunha, e, caso realizado nos anos cinquenta, transmitiria um conjunto arraigado de um imaginário sobre o sertão e o nordeste brasileiro muito afim à estética regionalista característica do seu período. Além de ter escrito um minucioso roteiro, ele buscou financiamento, locações, elenco, consultores de roteiro e pesquisadores. Outro projeto que enfatizaremos, ainda no escopo da obra de Lima Barreto, é o roteiro de Inocência. Conforme averiguamos por meio de pesquisa bibliográfica e de entrevistas, esse roteiro coliga uma interessante rede de transmissão e reforça um esforço de Lima Barreto de gerar um legado cinematográfico a partir do roteiro.

Por fim, decidimos analisar O Imponderável Bento contra o Crioulo Voador, de Joaquim Pedro de Andrade, que seria realizado em 1986. Caso filmado, esse roteiro seria um dos melhores retratos do Brasil em tempos de abertura, após duas décadas de ditadura. Ele também elucida sobre caminhos da geração do cinema novo, atrelada à Embrafilme, que tecia, nessa história não levada às telas, uma crítica direta e contundente ao regime militar. Sintomaticamente, a tríade de protagonistas são personagens diferentes que compunham a Aeronáutica desse período de transição. Passado em Brasília, e escrito em parceria com
Fernando Cony Campos, O Imponderável Bento contra o Crioulo Voador também dialoga com outros roteiros de Joaquim Pedro de Andrade escritos nos anos oitenta, como Vida Mansa e Casa Grande \& Senzala; histórias que seguem não filmadas e que apontam para uma mescla equilibrada entre o humor, que dialoga com a pornochanchada, sem se abster dos retratos alegóricos brasileiros que singularizam o cinema novo.

Optamos por realizar uma abordagem panorâmica de uma possível contribuição dos roteiros não filmados na historiografia do cinema brasileiro. Lado a lado, as histórias inéditas de Mário Peixoto, Vítor Lima Barreto e Joaquim Pedro de Andrade nos convidam a enxergar feixes e fendas históricas deixadas ao léu e à mercê dos ciclos que cada um desses diretores carregou consigo. Seja nas parcerias e nos desentendimentos com Ademar Gonzaga e Carmen Santos, como ocorreu com Peixoto; seja a contrapelo do fiasco do projeto industrial da Vera Cruz ou nas turvas relações entre o cinema novo e a ditadura, esses roteiros nos mostram gestos estéticos ciosos de sedimentarem estilos, obras, gêneros e autorias às telas.

\section{Sono Sobre a Areia - Onde a Terra Acaba (1933)}

De todos os roteiros que hoje constam no Arquivo Mário Peixoto, O Sono Sobre a Areia é, 
sem dúvida, o caso mais emblemático. Ele é a versão final, o chamado final draft, a orientar as filmagens que de fato ocorreram, em 1932, e acarretaram, direta ou indiretamente, no filme Onde a Terra Acaba. Inicialmente dirigido por Mário Peixoto, esse projeto acabou, após o embate de Peixoto com a Cinédia e Carmen Santos, com direção assinada por Otávio Gabus Mendes ${ }^{1}$.

No roteiro original, conta-se a história de Gupi e Eva, que se encontram numa remota franja praieira, no litoral carioca. Ele é um caiçara, um sujeito que está acostumado ao cotidiano da praia, da pesca e do convívio com as pessoas da região. Eva chega de barco, mas possui vínculos com a cidade, e um passado que será paulatinamente revelado ao longo da narrativa. O terceiro personagem essencial para a trama é Marco, que conhece os segredos dos dois, Eva e Gupi, que pouco a pouco tornam-se amantes. Transcrevo abaixo a caracterização dos personagens realizada pelo próprio Mário Peixoto, num dos documentos escritos para preparar a filmagem:

EVA - Uma mulher com um passado. Nome de empréstimo para aquela que surge na ilha e apodera-se da vida de Gupi, para além dos mormaços que o haviam subjugado, num perene êxtase diante das forças da natureza.

MARCO - 0 todo poderoso da ilha. Senhor de empregados de libré e pés descalços. Homem que se faz servir em copiosa baixela de prata, carregada em badejas de bambú, por seus pretos semi-escravos. Seu palácio é coberto de sapé e forrado de damascos, vindos da longínqua India. Sua alma complexa, sangra pelo segredo que um dia prendera àquela mulher.

GUPI - Um homem em rítmo perfeito com a natureza. Preza que facinada (sic) pela mulher, torna-se seu amante, vingando após a sua decepção, contra o próprio idealismo que, pouco antes, fôra sua religião .(PEIXOTO, 1931, p. 2)

Esse roteiro possui muitos tópicos que repercutem em outros vértices da obra fílmica de Mário Peixoto, como em Limite ou mesmo A Alma Segundo Salustre ${ }^{2}$. O teor trágico dos personagens, a ênfase num trio - dessa vez composto por dois homens, a existência de paixões e traições, a onipresença do mar e um contraste com o mundo urbano, o encontro entre caiçaras e sujeitos modernos e como um dialoga e anula o outro, constroem finalizado por Gabus Mendes e o filme inicialmente idealizado e dirigido, embora incompleto, por Mário Peixoto. 0 que torna a situação mais complexa é o fato do filme Onde A Terra Acaba encontrar-se atualmente perdido, o que nos impossibilita de realizar qualquer ensaio de cotejamento e comparação entre o roteiro de Peixoto e a versão final de Otávio Gabus Mendes.

2 Sobre uma análise de Alma Segundo Salustre, ver Gonçalo (2018). 


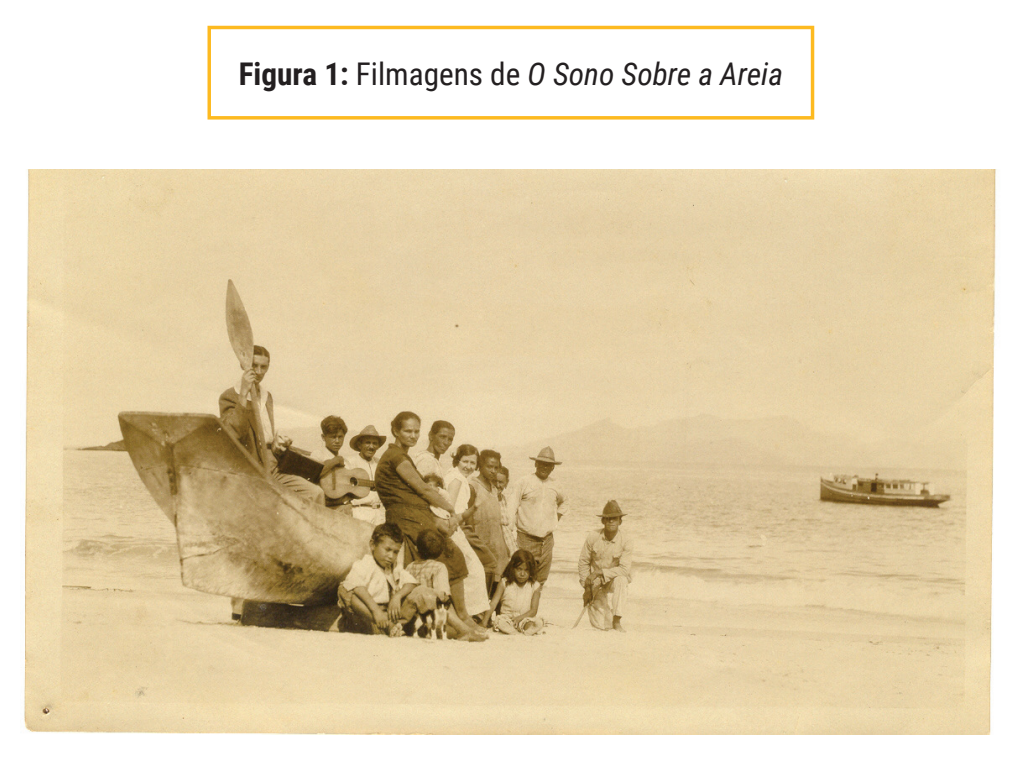

Fonte: Arquivo Mário Peixoto (1933).

uma estética cinematográfica que combina paisagens com o retrato das almas dos seus personagens.

O Sono Sobre a Areia, no entanto, conta principalmente o encontro de Eva com Gupi. Caso tivesse sobrevivido, o filme mostraria um pequeno e fugaz paraíso, que pulsou junto aos seus protagonistas. No começo da história e do idílio, tudo soa pacífico, perfeito, e os problemas parecem tão distantes como as águas que separam a ilha do mundo urbano e da modernidade. Misteriosamente, Eva emerge de um barco que dá na praia e, à primeira vista, encontra Gupi. Eva e Gupi apaixonam-se, mas abdicam das palavras para viver esse júbilo. Na ilha, eles respiram uma existência silente, uma ambiência poética que Peixoto sabe coser com notória destreza, e que remete a uma precisa continuidade com a estética silenciosa de Limite.
Peixoto, aliás, evoca o mar e a ambiência litorânea que coliga, uma vez mais, O Sono Sobre a Areia a Limite. Ambas as histórias estão atreladas à paisagem, ao local e ao território por onde passam os protagonistas. Subitamente, o ambiente psicológico sofre uma significativa mudança. Marco começa a chantagear Eva e Gupi. Ele detém a história dos seus passados, sabe dos seus segredos e foi picado pelo ciúme diante da felicidade daquele casal. $\mathrm{Na}$ sua mala, Eva trouxe uma máquina de escrever. Ela está inspirada e descreve o que vê: Gupi, a paisagem litorânea. Numa das cenas, Gupi segura um coco, que cai no chão. Ele está nervoso e quer ler o que Eva está escrevendo sobre ele. Olhando-o, Eva fuma. Gupi, então, lê uma das páginas: "Um sonhador". "Ressureição, vida e morte de um selvagem: um nativo no nosso século". "Um romance", é uma das palavras que Gupi capta. "Fim". Eva, nessa hora, apaga seu cigarro. Ela fita-o, 
e diz: "Estou pronta" (Регхото, 1933, p.5). Gupi fica furioso, violento e começa a bater em Eva, de forma agressiva e súbita. Como a maioria das histórias escritas por Mário Peixoto, O Sono Sobre a Areia também possui um trágico desfecho.

\section{Figura 2: Filmagens de 0 Sono Sobre a Areia}

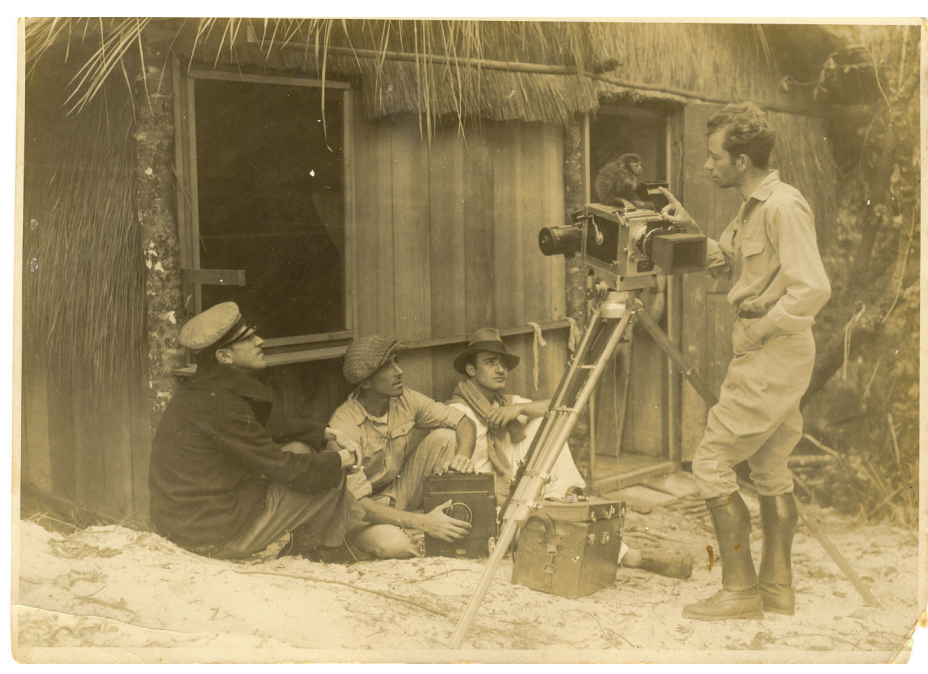

Fonte: Arquivo Mário Peixoto (1933).

Essa estranha e impactante história continua na sequência dos seus pontos de virada. No entanto, é importante salientar o papel desempenhado por Carmen Santos - atriz e produtora do filme - e relembrar como O Sono Sobre a Areia foi perdido. De fato, esse roteiro foi quase integralmente filmado, e as poucas sequências que sobreviveram podem ser encontradas no documentário Onde a Terra Acaba (2002), de Sérgio Machado. O roteiro, num contraste, é o único vestígio histórico do filme imaginado, criado e dirigido por Mário Peixoto. Durante o set, Peixoto e Carmen Santos tiveram alguns desentendimentos, o que acarretou na sua desistência do projeto. Como ela era a produtora, as filmagens também precisaram ser interrompidas. Embora boa parte do roteiro já tivesse sido, de fato, filmada, O Sono Sobre a Areia permaneceu como uma obra incompleta, e com certo teor etéreo. Ademais, Carmen Santos requisitou seus direitos de produção e decidiu por escrever outra história, aproveitando parte do material rodado por Peixoto. Ela, contudo, concebeu uma narrativa completamente diferente, inspirada numa adaptação de Senhora, romance de José de Alencar, que acarretou no filme Onde a Terra Acaba, assinado por Otávio Gabus 
Mendes (PESSOA, 2002). Essa experiência foi realmente traumática para o então jovem Mário Peixoto, que nunca mais voltou a dirigir nenhum dos tantos roteiros que escreveu ao longo da sua vida.

Existe, no entanto, um sutil e intrigante detalhe que chama a atenção desse segundo filme-roteiro de Peixoto, sobretudo quando contrastado com Limite. Esses detalhes culminam nos beijos fílmicos. Quando apaixonados, Gupi e Eva vivem uma longa e tocante sequência de beijo. Em Limite não encontramos nenhuma cena minimamente similar - o que o torna, portanto, um filme sem beijos. Quando, por outro lado, lemos outros roteiros assinados por Peixoto, deparamos com uma interessante pletora de sequências de beijos. São cenas trágicas, como as que ocorrem em A Alma Segundo Salustre e Outono/Jardim Petrificado, nas quais os beijos dos personagens coligam-se, narrativamente, às pulsões de morte (GONÇALO, 2018).

Tais sequências de beijo situam-se numa intrigante fronteira interpretativa. Beijos como o de Eva e Gupi quedam, até o momento, apenas no papel. São beijos ficcionais, mas que convidam à uma imaginação específica, que ora é literária, ora é cinematográfica. No caso dos roteiros não filmados, no entanto, e nas sequências de um conjunto de roteiros escritos por Peixoto, essas cenas abrem o flanco de beijos especulativos ou, em outras palavras, de uma arqueologia especulativa ${ }^{3}$, que aponta, paradoxalmente, tanto para a negatividade desses acontecimentos - históricos e cinematográficos - quanto para a sua potência e abertura de possibilidades fílmicas em tempos e leituras presentes.

De acordo com esse viés de uma arqueologia especulativa, o roteiro de O Sono Sobre a Areia obtém uma outra fresta e relevância histórica. Sem exagero algum, ele transforma-se em um único arquivo, um remoto vestígio de um filme que foi realizado, radicalmente modificado e, posteriormente, perdido. Como se fosse uma sombra das primeiras intenções de Mário Peixoto, as quais foram diluindo-se e delindo seus próprios rastros. Casos

30 conceito de Arqueologia Especulativa (GONÇALO, 2018) inspira-se na arqueologia das mídias e propõe o método especulativo para lidar com acontecimentos incompletos, fragmentários ou inacessíveis dentro da história do pensamento, das mídias e, no caso dos roteiros, do cinema. A face arqueológica remete a um passado submerso como os roteiros marginais. A vertente especulativa, por sua vez, enfatiza o devir de filmes futuros, que todo roteiro não filmado sugere. 0 método especulativo é proveniente de (WHITEHEAD, 1978) e aguçado pela recente guinada especulativa (HARMAN, 2018; MEILLASSOUX, 2012), a qual convida a filosofia ocidental - diante da "bifurcação da natureza" e do "co-relacionismo" - a inspirar-se nos exercícios mentais da metafísica supor objetivamente acontecimentos fugidios à efetiva compreensão humana. 0 realismo especulativo, por outro lado, fornece os fundamentos filosóficos para a guinada animal e toda a reflexão não humana ou mais humana, que guia algumas inquietações do pensamento contemporâneo. 
como o de O Sono Sobre a Areia inserem um impasse nas consolidadas formas de análise de roteiros. Eles não são nem o vestígio de um roteiro blueprint, nem o roteiro não filmado tout court, ancorado num modelo que privilegia a especulação. Não propiciam um gesto arqueológico retrospectivo, de reconstrução de um processo que não houve, que não se encerrou. Tampouco acenariam para uma arqueologia prospectiva e especulativa, em filmes que ainda poderiam ser realizados. Por enquanto, é fundamental frisar como a obra fílmica de Mário Peixoto não pode ser, em termos históricos, delimitada, circunscrita ou mesmo fechada ao redor de Limite.

\section{Vítor Lima Barreto e 0 anseio do roteiro como um legado}

A relação de Vítor Lima Barreto com o roteiro é, em termos pessoais e históricos, bastante diferente quando contrastada com a de Mário Peixoto. Embora ambos compartilhem da importância dada ao ato de escrever detalhadamente suas cenas e sequências nas páginas, o papel do roteiro para o cinema brasileiro já havia passado por significativas alterações. Em comum, Peixoto e Barreto viam o roteiro a partir de um paradigma literário. Com Mário, no entanto, temos um roteiro mais próximo de um solipsismo lírico. Barreto, por sua vez, acena para um vínculo com a literatura regionalista brasileira dos anos trinta e quarenta, a qual possui o nordeste como seu principal imaginário. Resguardadas as semelhanças, deve-se salientar que nem mesmo a compreensão do termo roteiro possui mesmo significado histórico. Numa palavra, com Lima Barreto pode-se afirmar que o roteiro passa, pouco a pouco, a obter um reconhecimento profissional.

Num artigo seminal, Heffner (2012) ressalta a centralidade desse período na consolidação do roteiro no cinema brasileiro. É quando podemos perceber ao menos uma intenção de tornar o roteiro como um instrumento autorreferente, seja pela aproximação dos escritores freelancers, seja pelo momento em que o roteiro passa a exercer uma certa expectativa por parte da indústria cinematográfica. Vale ressaltar que, nos anos cinquenta, o modelo do roteiro Blueprint já estava consolidado em Hollywood e, pela rápida disseminação de manuais de roteiro, expandia-se pelo mundo. Heffner (2012) chama a atenção para a disseminação feita pelo crítico Alex Vianny, quando, depois de uma temporada nos Estados Unidos, traz em sua mala um exemplar de Theory and thechnique of playwright and screenwriting (1960), de John Howard Lawson, uma espécie de bíblia para os roteiristas independentes dos anos quarenta.

Ao declinarmos para o caso brasileiro, a dramaturgia já vinha esboçando, ao seu modo, inquietações similares. No desejável percurso 
de uma história do roteiro no Brasil, é essencial salientar dois anseios paralelos. O primeiro é uma vontade de institucionalizar a prática do roteiro nos estúdios, mas também nessa passagem entre a dramaturgia, a literatura e o ímpeto de migrar essa organização da prática de roteirização para um campo mais profissional. As experiências de Alinor Azevedo (MELLO, 2005), mais próximas da Atlântida e da chanchada, por um lado, coadunam-se ao empreendimento da Vera Cruz. O segundo refere-se à busca por uma dramaturgia mais genuinamente brasileira. É preciso evitar um anacronismo para os aspectos que envolvem o termo do nacionalismo, mas vislumbra-se, nessa intenção, uma inclinação a buscar narrativas, mitologias, lendas, histórias e inspirações literárias que dialogassem mais diretamente com o contexto da cultura brasileira. Na década de trinta, por exemplo, temos o caso de Oduvaldo Viana, que migra da dramaturgia para buscar um diálogo criativo com a técnica hollywoodiana.

Nesse contexto, é importante destacar o papel central, nos anos quarenta, desempenhando pela figura histórica de Alberto Cavalcanti. O diretor brasileiro, até então radicado na Inglaterra, elaborou reflexões essenciais para compreender os caminhos abertos pelo roteiro. Um desses escritos é o relatório sobre o cinema brasileiro, o Instituto Nacional de Cinema, encomendado diretamente por Getúlio Vargas ${ }^{4}$. Conhecido e já estudado em outras ocasiões (souzA, 1998), esse relatório chama a atenção para a sua extensão, o seu detalhamento e sua ousadia, que era, nada mais, nada menos, de direcionar uma política estatal para a implementação industrial do cinema brasileiro.

O primeiro fato que ressaltamos é o de Alberto Cavalcanti encontrar-se nas pontas opostas de dois projetos bem diferentes de industrialização do cinema brasileiro. De um lado, um projeto amplamente privado - "burguês", se seguirmos a canônica leitura de Maria Rita Galvão - e, de outro, o desejo de colaborar na institucionalização de um cinema nacional, totalmente incentivada por uma política estatal. No meio dessas duas tendências, e com uma experiência de fato privilegiada, o relatório compartilha, logo nas suas primeiras páginas a seguinte pergunta: "Como imprimir ao público um produto de baixa qualidade técnica?" (CAVALCANTI, 1951). A pergunta não é fortuita e coincide com uma constante constatação do cinema da época: os acontecimentos 
no cinema brasileiro possuem pontuais interações com um público ou uma audiência. Em termos econômicos, trata-se de um produto predominantemente importado, vindo de outros países, do exterior. Seguindo as palavras do relatório: "O que não resta a menor dúvida, no entanto, é que um short filmado sem argumento prévio e sem diretor jamais deixará de ser uma simples reportagem. E uma reportagem sem o apoio indispensável pode nunca ser uma boa reportagem" (CAVALCANTI, 1951). Nos anos cinquenta, portanto, o roteiro passa a ser uma exigência inconteste para o cinema brasileiro dar um passo rumo à sua autonomia e efetiva industrialização.

Parte importante da trajetória profissional de Lima Barreto vai de encontro com essas inquietações de Cavalcanti (1951). Lima Barreto não apenas foi seu assistente, e realizou sua "formação" sob a sua régia, quando Cavalcanti era o onipotente na Vera Cruz. É sob esse amplo contexto de uma ânsia por institucionalização do roteiro que O Sertanejo precisa ser compreendido. Ao ler as reportagens, podemos destacar três momentos diferentes na obstinação do diretor Lima Barreto em realizar o seu filme O Sertanejo. O primeira é sobre a originalidade do projeto. O roteiro escrito pacientemente por Lima Barreto é uma adaptação de Os Sertões, de Euclides da Cunha, que é, até onde temos conhecimento, seria um acontecimento sem precedentes ${ }^{5}$. Durante a série de reportagens que coletamos sobre esse projeto, constatamos como ele de fato não foi realizado por motivos financeiros e já estava relativamente adiantado.

Com uma versão finalizada do roteiro, Lima Barreto buscava elenco, locações, parcerias e fazia encontros, de acordo com os jornais nordestinos, como uma forma de divulgação das suas filmagens, que estavam por vir. O ano de 1953 foi especial na biografia de Lima Barreto. Segundo as reportagens que destacamos neste ensaio, Lima Barreto acabava de casar e era tratado, por onde passava, com uma celebridade, dada a sua recente consagração em Cannes com O Cangaceiro. As reportagens apontam que Lima Barreto já tinha alguns cantores escolhidos para o elenco. Vale destacar a escolha do sambista Adoniran Barbosa para atuar como Antonio Conselheiro. A ênfase no musical era, de uma

5 Apenas no contexto do Cinema Novo, cerca de uma década depois, essa aproximação seria de fato reestabelecida, sobretudo em Deus e o Diabo na Terra do Sol (1964), de Glauber Rocha. No seu livro Sertão Mar, Xavier (2002) realiza, inclusive, uma comparação entre o projeto de representação regional do nordeste no cinema brasileiro, trazendo à luz o contraste entre 0 Cangaceiro e o filme de 1964 do cineasta baiano. Embora não tenhamos ainda feito uma análise minuciosa do roteiro, mais especificamente porque ainda não o encontramos, a sua importância histórica na compreensão do compasso do cinema brasileiro revela-se essencial. 
Figura 3: Reportagem sobre a leitura pública de 0 Sertanejo

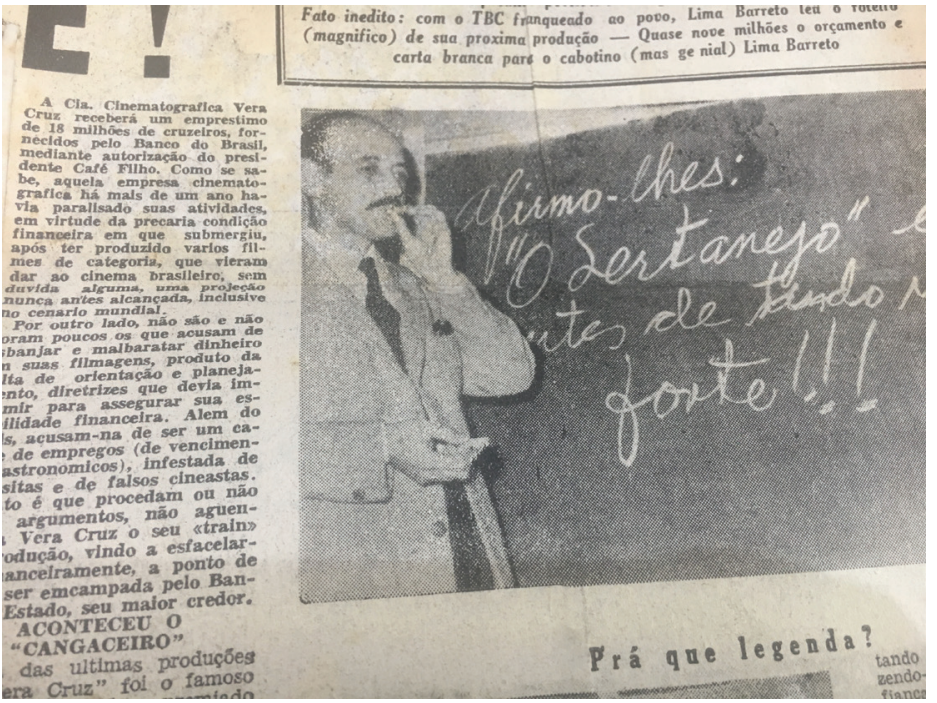

Fonte: Última Hora (1955).

Figura 4: Trecho publicado de 0 Sertanejo

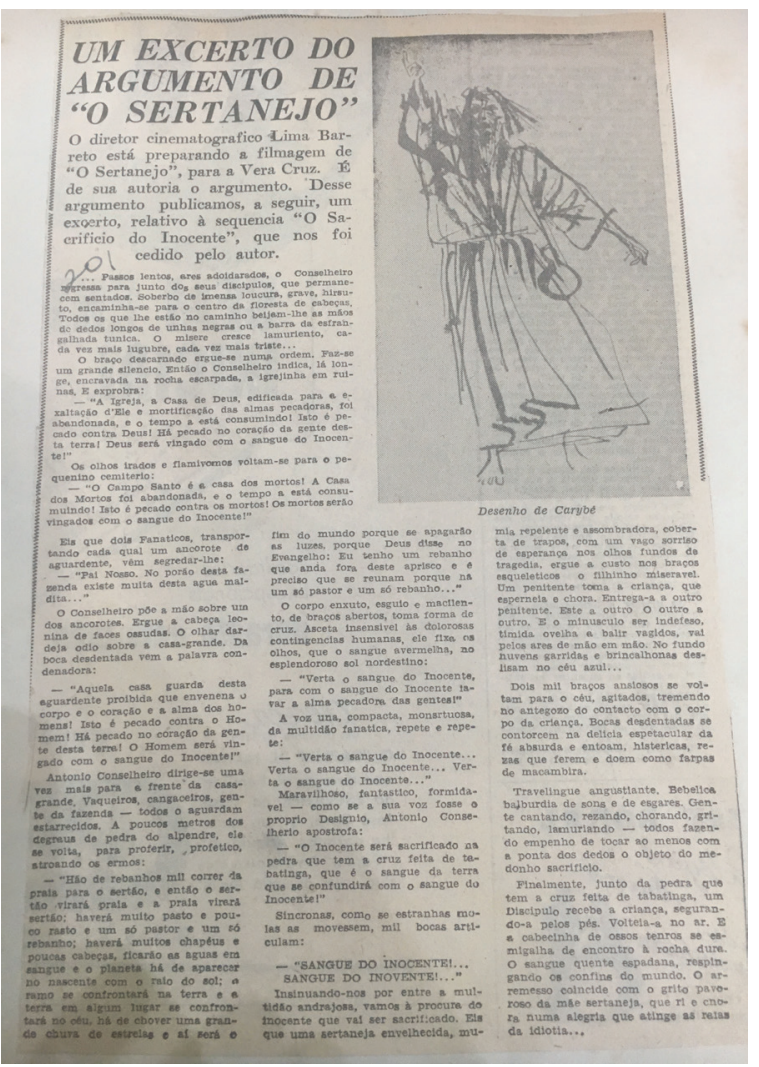


forma que ainda não conseguimos decifrar, uma sugestão muito forte na condução e direção do filme.

Num segundo momento, as reportagens revelam a frustração de Lima Barreto. Ele realmente não consegue recursos para a realização de O Sertanejo. Seja pela Vera Cruz, que se encontra com dificuldades financeiras, seja pela procura de outras fontes de recursos. Uma reportagem, por exemplo, indica ele procurando Alzira Vargas, influente filha do então presidente Getúlio Vargas. Lima Barreto convida-a para interpretar um papel no seu filme, num movimento que talvez denote a vontade de obter recursos oficiais. No seu afã grandiloquente, e um tanto curioso, Lima Barreto afirmava que gostaria de filmar O Sertanejo em esperanto, como uma forma de expressar a universalidade dessa história nordestina.

Após essas notícias da não realização de O Sertanejo, as reportagens também apontam outros movimentos interessantes. O primeiro é o da publicação de trechos do roteiro em jornais de grande circulação, que seria um fato inédito. Anteriormente, as publicações de trechos do roteiro eram restritas a revistas especializadas em cinema, como são os casos da Scena e da Revista de Cinema. O objetivo de Lima Barreto, nesse contexto, era de trazer mais interesse para a sua adaptação e de persistir na realização da sua filmagem. O segundo momento são os anúncios das leituras públicas do roteiro de O Sertanejo, que, segundo fotos publicadas nos jornais, tinha condução, debate e até certos trejeitos de palestra realizada por Lima Barreto. Nesse caso, os roteiros deixam de ser apenas um aparato técnico e um encaminhamento às filmagens. Eles passam a ter, carregar e transmitir uma certa áurea literária e artística.

Paulo Emílio, Alex Viany e outros críticos e historiadores do cinema brasileiro, frequentaram algumas dessas leituras, que ocorreram no Rio de Janeiro e em São Paulo, e eram anunciadas nos jornais dessas cidades. Há uma emblemática e famosa frase de Paulo Emílio Salles Gomes que afirma ser O Sertanejo, de Vítor Lima Barreto, o filme brasileiro mais comovente que ele "já viu" (CALIL, 2018). Ressalto e retenho, momentaneamente, as aspas da expressão “já viu”. Afinal, como se sabe, O Sertanejo, a despeito da incansável obstinação de Lima Barreto, nunca alcançou lentes, câmeras e telas - e é, desde os anos cinquenta, um dos roteiros não filmados mais citados, conhecidos e, por assim dizer, antológicos do cinema brasileiro. A frase de Paulo Emílio reforça como um dos filmes mais brasileiros "mais belos" seria uma obra ainda no papel, ainda a migrar às telas, incompleta, e, portanto, não consolidada historicamente. 
Embora depois de O Cangaceiro, Lima Barreto tenha realizado poucas filmagens, ele permaneceu escrevendo roteiros. Em entrevistas realizadas com Walter Lima Jr. e Carlos Augusto Calil, ambos contaram a este autor como, ao final da vida, Lima Barreto carregava consigo um velho baú com todas as adaptações e os roteiros que gostaria de ter filmado. Eles ficavam com ele no quarto do asilo onde morou, pobre, à margem de qualquer celebração, e lá ficou até morrer em 1982. Entre as tantas adaptações e projetos depositados no velho baú, estava lá o roteiro de Inocência, caso que melhor ilustra um círculo "virtuoso" de transmissão de tradições pelo roteiro e sua concisão dramática-imagética às gerações futuras.

Walter Lima Jr. narra um pouco dessa história e como o roteiro chegou até ele. Mais do que uma obra original de Lima Barreto, esse projeto foi fruto de uma interpretação do roteiro de Humberto Mauro, ambos como resultados de uma adaptação do romance homônimo de Visconde de Taunay. Segundo essa narrativa, Lima Barreto teve conhecimento da intenção de Mauro de filmar essa obra quando o visitou, durante a sua lua-de-mel, na sua fazenda. O roteiro de Humberto Mauro tinha pouco mais de duas páginas, era sucinto. Lima Barreto, portanto, parte desse roteiro para engendrar a sua interpretação, tanto à obra original, de Taunay, quanto à estética regionalista de Humberto Mauro.

Lima Barreto não chega a filmar esse roteiro. No começo dos anos oitenta, Walter Lima Jr., que já pensava em adaptar Inocência, vê na televisão uma reportagem sobre o caso de indigência do diretor de O Cangaceiro. Ele aborda Carlos Augusto Calil, então diretor da Embrafilme, e interpela-o para a empresa governamental adquirir os direitos autorais do famoso cineasta. Walter Lima Jr. fica encarregado pelas negociações. Pega um avião e vai a encontro de Barreto (MATTOS, 2002). O cineasta carioca relata que foi uma negociação difícil, mas ao final conseguiu ter acesso a meia dúzia de roteiros, todos zelosamente encadernados ${ }^{6}$. Pronto: estava feita a transmissão, e traçada a ponte geracional. De Taunay a Mauro, de Mauro a Barreto e deste a Walter Lima Jr., tal como uma preciosa tocha passada de mãos em mãos, entre décadas, até alcançar os olhos do espectador no filme dirigido por Walter Lima Jr., com atuação de Edson Celulari e Fernanda Torres. Num dos desfechos mais interessantes dessa narrativa, Walter Lima Jr. conta que no último dia de set, coincidentemente, morreu Lima Barreto. Na cena final do filme, uma borboleta sai da sua 
crisálida, da sua densa e peculiar hibernação histórica e biológica.

À parte dos casos e das coincidências, essa história do roteiro de Inocência elucida e reforça vários gestos e intenções que foram caros a Vitor Lima Barreto. Em primeiro lugar, há a compreensão do roteiro como uma peça fundamental, seja para a filmagem, seja para uma migração histórica que transcendem as limitações da produção cinematográfica. No papel, seus filmes possuem uma aura literária no sentido de apostarem numa sobrevivência estética para além da sua circunscrição histórica. Num caso como o de Inocência, os roteiros não filmados adentram, por assim dizer, certo "círculo virtuoso", que permite saltos cronológicos de uma tradição dramática cinematográfica. Trata-se, obviamente, de uma tradição inventada, que coliga escritores e cineastas de tão diferentes cepas. Os roteiros não filmados de Lima Barreto apontam, de forma veemente, para esse desejo, no qual a vontade de migrar as palavras nas páginas para as cenas na tela também perpassem, tal como numa peça de teatro, diferentes tempos, leitores, públicos ou mesmo espectadores.

\section{Os roteiros não filmados a contrapelo da história}

Na cinematografia brasileira, - e mesmo na sua literatura - costumam ser escassas as representações mais diretas de militares. Já num curta e documentário seminal como Brasília, Contradições de uma Cidade Nova (1967), Joaquim Pedro de Andrade mostra fotos dos militares como alguns dos últimos moradores do Palácio da Alvorada. Vê-se, então, uma montagem que intercala imagens de João Goulart, Jango, num close, e cercado por generais; em seguida, após o golpe de 64, fotos dos Generais Castelo Branco e Costa e Silva. Todas essas fotos seguem acompanhadas ao som de passarinhos, conotando uma discreta ironia.

Realizado às vésperas do AI-5, e posteriormente censurado, o curta anunciava o colapso do projeto modernista, que colocava Brasília nos holofotes das vanguardas mundiais. De forma amarga, o documentário reconhece que o projeto de Brasília fracassou justamente por não universalizar as linhas de Lúcio Costa e Niemeyer para além das fronteiras do Plano Piloto. Dentro da cinematografia de Joaquim Pedro de Andrade, Brasília, os militares e certos fracassos brasileiros eram frequentemente entrelaçados.

Essa assertiva é corroborada por um dos melhores roteiros não filmados do diretor carioca. O Imponderável Bento contra o Crioulo Voador chama a atenção, inicialmente, por assumir um retrato frontal dos militares. Escrito em 1986, e, portanto, nos anos que hoje chamamos como os de "abertura" democrática, Joaquim Pedro de Andrade não hesita em 
aproximar os militares de personagens caricatos, como se fosse típicas figuras oriundas da (porno)chanchada.

Os protagonistas desse roteiro são todos da Aeronáutica. Eles chamam-se Mauro, Bento e Larroque - este último o comandante da base aérea e manda-chuva na corporação que comprou O Correio de Brasília, influente jornal da capital federal. O início do roteiro é permeado por perseguições e paranoias. Subitamente, Mauro é convocado no seu apartamento funcional para uma "ação instrutiva”. Enquanto dirige, Larroque metralha aos ouvidos do subalterno: "Nós estamos vivendo uma época grave de nossa história. Perigosa, muito perigosa. A subversão está infiltrada por todo lado. Nos colégios, na universidade, na Igreja, na imprensa, e até, o que é mais grave, nas próprias forças armadas. E você, Mauro, anda se reunindo com essa gente" (ANDRADE, 1990, p. 16). Em seguida, Larroque leva Mauro a uma sessão de tortura que resulta num assassinato diante dos olhos de vários colegas de farda. Mauro entra em pânico, mas Larroque quer apenas a sua cumplicidade. Implicitamente, sugere-se que o comandante esteja diretamente envolvido com os agentes que tocavam os porões da tortura durante a ditadura.

Taís é a sedutora jornalista que enlaça a tríade fardada. Casada com Mauro, ela é amante de
Bento e flerta com Larroque, que impulsiona sua carreira de colunista social do Correio de Brasília. Mais do que amante, Taís concentra o jogo de chantagem e boicotes envolvendo os interesseiros personagens que passeiam entre porões, voos, sessões de reza mística, almoços na churrascaria do lago Paranoá, champanhes e vernissages. Paulatinamente, o roteiro ruma para um crescente desvario, que remete aos melhores trechos de Macunaíma (1969), também de Joaquim Pedro. Algumas cenas parecem absurdas, mas também tecem a alegoria de uma geração. Súbitas levitações, deliberadamente inspiradas em Simão no Deserto (1965), de Luis Buñel; orgias kitsch e pretensamente sofisticadas combinam-se com a ganância cara à capital do país, com reuniões regadas a uísque e cocaína, intrigas e baixarias nas redações de jornais, fotógrafos fabricando imagens para as capas das fake news da época.

Sobrevivente de um desastre de avião, Bento, o “imponderável”, cai de paraquedas (literalmente) no meio de uma comunidade de anacoretas e ermitões místicos que vive no cerrado. Uma pedra levanta-se do chão e de dentro do buraco sai Isidoro, que agradece, aos prantos, a pouca comida de que dispõe. No sítio desses eremitas, está o "pensatório", cenário de sermões, levitações, autoflagelações e uma tensa e ambígua negação dos prazeres carnais. Depois de um árduo treinamento, Bento passa a flutuar e regressa 
a Brasília, a capital vigiada pelos milicos. Ele torna-se uma irônica ameaça àquela estratégica zona aérea.

O melhor do roteiro está na forma como seus chistes são harmonizados com reflexões históricas e políticas. Numa das suas sequências mais próximas da pornochanchada dos anos setenta, Taís vai com uma trupe de mulheres e amigos gays à Soceila, misto de salão de beleza com prostíbulo, na Ceilândia. De lá elas vão importunar a abstinência sexual de Bento e sua seita, pois reza a lenda que esses homens santos, depois de tanta sublimação, suscitam orgasmos únicos às mulheres que transam. O resultado é uma memorável sequência de vaginas falantes, mulheres rasgando as vestes dos monges, algo caro a um poder do matriarcado que Joaquim Pedro de Andrade representou em O Homem do Pau-Brasil (1981), seu lendário filme, que adapta parte da obra de Oswald de Andrade.

Dependendo de como seja lido (ou filmado), O Imponderável Bento contra o Crioulo Voador pode não passar de uma comédia de costumes do Brasil dos anos oitenta. Num olhar mais minucioso, contudo, seus personagens nos dizem muito sobre hábitos e comportamentos comuns após décadas de autoritarismo militar no Brasil. Mauro é um "traidor" das forças armadas e acaba sucumbindo à crueldade dessa instituição - é o tipo suicida. Bento trai o amigo e colega, descamba para o misticismo como se representasse o desbunde ou o abandono de qualquer perspectiva política. Camaleônica, Taís trai a todos e é por todos traída, transita por conchavos e oportunismos, é cínica, vingativa, abusada por Larroque, mas também dócil nos seus afagos protetores quando está junto de Bento. Na história, ela só alcança autonomia quando passa a exercer o sujo jogo das chantagens machistas que a cerca por todos os lados. É por trás dessa trama de traições que Larroque circula, sedento por manter-se no poder e por controlar os ares de Brasília. Ele comete atos ilegais, tortura, mata, abusa, estupra e não é repreendido por instituição alguma. Apita, manda e desmanda na base, nas ruas, nas capas de jornais, nos conglomerados econômicos e exige suas recompensas entre as paredes do quarto dezoito do motel Três Poderes.

São várias as temporalidades históricas articuladas pelo roteiro de Joaquim Pedro, que foi escrito em parceria com Fernando Cony Campos e Eloá Jacobina. A primeira dobra histórica remete à anistia, instrumento jurídico que possibilitou brechas aos julgamentos dos crimes de Estado cometidos por militares e às formas de resistência, armada e civil, que os contestaram. Embora o filme pareça ocorrer entre os últimos anos de ditadura e os primeiros de abertura, os militares circulam livres, leves, soltos e à vontade, como se ainda 
permanecessem no comando da capital - e do país. Os demais personagens estão acuados. Ora são perseguidos, ora precisam entrar no jogo de favores do comandante.

O roteiro também acena para uma revisão crítica do Cinema Novo. Além de flertar com a pornochanchada - e fazer chacota política com tiradas sexuais - inclui-se o misticismo como um elemento bem diferente dos primeiros filmes da geração do cinema novo, nos quais a religião era comumente representada como uma alienação popular que impediria uma transformação política. Levitando, os personagens trazem pitadas de humor e enfatizam um misticismo vago, híbrido, distinto das religiões mais tradicionais; flertam com um realismo mágico que consegue comentar criticamente os costumes sem se afastar dos paradoxos da nossa complexidade cultural. Com diálogos envolventes e uma linguagem atenta a expressões populares, corriqueiras, coliga-se a antropofagia oswaldiana com a tragédia do cotidiano à Nelson Rodrigues. O filme, no entanto, não consegue se afastar dos pontos de vista do racismo cordial. É o que ocorre com o crioulo do título, que como personagem revela-se apático, e acaba sendo representado de forma estereotipada pelos autores, sem subjetividade nem protagonismo.

Num último estrato histórico, O Imponderável Bento contra o Crioulo revela-se um dos mais peculiares roteiros não filmados da história do cinema brasileiro. Primeiro, ele permite acessar o ímpar imaginário geracional do país nos idos dos anos oitenta. Voa-se junto com a empatia dos seus personagens pelos ares que aglutinam a ficção fílmica com a imaginação de uma época. Todo roteiro não filmado, como argumentamos nessas linhas, expõe uma fratura temporal, genuinamente especulativa, e torna-se o sintoma de uma história cindida. São filmes que ainda repousam no papel, que não migraram para telas, não obtiveram sessões nem contato com um público.

Embora O Imponderável Bento Contra o Crioulo Voador seja o roteiro mais ilustrativo da carreira não filmada de Joaquim Pedro de Andrade, ele dialoga com outros dois projetos seus, também não filmados, e ambos escritos nos anos oitenta. O primeiro roteiro é Casa-Grande \&Senzala, que estava pronto para ocorrer pouco antes da morte do diretor carioca. Publicado pela editora Aeroplano, o roteiro de Casa-Grande $\&$ Senzala é acompanhado por um amplo material, como fotos, decupagens, entrevistas, relatos de viagens, de visitas a locações e uma introdução que traduz bem ao leitor o espírito do projeto que estava sendo conduzido por Joaquim Pedro de Andrade.

O roteiro não segue exatamente a clássica obra de Gilberto Freyre. Tenta, ao contrário, alinhavar a formação histórica (e íntima) do 
Brasil. Se fosse filmado, certamente seria a obra mais alegórica e mais próxima de uma interpretação direta do país, equivalente, talvez, à Macunaíma (1969), no arroubo de ver pela história - ou pela alegoria, rastros da totalidade da nação. Na sua história do Brasil, tendo Freyre como guia, Joaquim Pedro retorna ao encontro entre Pero Vaz de Caminha com os habitantes ameríndios, enfatiza a violência sexual, a chegada dos escravos e um início de socialização que são salpicados por casos os mais diversos. Em seguida, tece uma linha cronológica até chegar à instalação da Casa-Grande. Dentro dessa ampla perspectiva histórica, Joaquim Pedro opta, no roteiro, por iluminar as microficções, os casos passageiros que passam de forma afim e similar nas páginas mais conhecidas do clássico dos anos trinta, escrito pelo antropólogo pernambucano.

Vida Mansa (1980) é o terceiro roteiro de Joaquim Pedro de Andrade que resumiremos nestas linhas. As cenas iniciais ocorrem em Belo Horizonte, no contexto de um apartamento de classe média. Inês acorda e percebe que ela é casada. Inês, no entanto, deixa seu apartamento, encaminha-se a um telefone e avisa Marina, sua amiga que mora no Rio de Janeiro, que está tomando uma decisão. Abandona tudo e todos da sua família - mesmo a sua filha, e vai mudar de vida. Pede um abrigo. Precisa ficar distante do marido. Tinha, enfim, decidido pela separação.

Se compararmos com os filmes de Joaquim Pedro contemporâneos à Vida Mansa, como Crise Conjugal (1975) e A Mulher do Pau-Brasil (1982), constata-se que o diretor carioca primava por construir um ritmo dramático que tinha o cômico, o chiste e as aventuras sexuais dos seus protagonistas como algumas das suas principais inquietações. Com Inês não foi diferente. Ao encontrar Marina, já no Rio, ambas as suas amigas saem em direção aos bares de paquera no subúrbio da cidade. Entrementes, Eduardo, o marido abandonado, passa a ligar insistentemente para Marina, que disfarça e, cúmplice de Inês, diz ao ex não saber nada da amiga. São falas cômicas que apontam para certos vetores ridículos que tenderiam a acompanhar as comédias de separação brasileiras nos anos oitenta. Depois de desligar o telefone, por exemplo, Eduardo comenta o episódio com a mãe, que está ao seu lado e diz: "Coitado do meu filho.... um corno". Ao que Eduardo, irritado, replica: "Corno é o caralho, mãe! Corno é o caralho" (ANDRADE, 1980, p. 20).

Marina e Inês, contudo, conhecem Xavier, num dos botecos que frequentavam. O que ocorre daí em diante é um puro desvario. Xavier possui uma namorada, mas Marina e Inês acabam indo visitá-lo no Sítio Três Corações e vivem intensos momentos de orgia e libertação. 
A namorada de Xavier, no entanto, continua a ir lá. Numa das cenas mais inusitadas, Marina e Inês matam Xavier e sua companheira e passam a morar, calmamente, no sítio. Embora cadenciado por um plot que aparentemente soa clássico e coadunado à comédia ligeira e de costumes, ao final, Joaquim Pedro de Andrade esboça um retorno a temas caros da sua pesquisa estética, de influência modernista e de Oswald de Andrade, como o matriarcado e a antropofagia.

O que o contraponto desses três roteiros de Joaquim Pedro de Andrade poderia nos dizer? Inserido em contraste e no conjunto com outros filmes do Cinema Novo dos anos oitenta, percebe-se como Joaquim Pedro de Andrade estava afinado às inquietações estéticas e políticas da sua geração. Há, em Vida Mansa, uma representação de uma libertação violenta, levada a cabo pelas personagens Inês e Marina. Já em O Imponderável Bento contra o Crioulo, a violência ganha contornos de uma representação bem ácida das heranças do regime militar e ditatorial, mas é também uma coação institucionalizada, cotidiana e que conduz a população a um tipo bem específico de delírio. Pode-se afirmar, nessa linha interpretativa, que a obra não filmada dos anos oitenta de Joaquim Pedro de Andrade adensa e complementa o seu mordaz retrato dos costumes e da violência historicamente instalados no seio da sociedade brasileira.

\section{Considerações finais}

Qual seria a contribuição dessa arqueologia especulativa dos roteiros não filmados de Mário Peixoto, Lima Barreto e Joaquim Pedro de Andrade? Nas linhas acima, tentamos salientar diferentes vértices que aqueles roteiros permitem vislumbrar dessas obras. No caso de Peixoto, os roteiros não filmados revelam feixes de uma obra submersa e que quantitativamente ultrapassam o caso único de Limite. Nos seus textos fílmicos, Peixoto acena para uma possível completude de uma obra fílmica, que talvez possua tanto ou mais relevância do que seu projeto finalizado. Nesse sentido, descobrir o cineasta Peixoto passaria por lidar frontalmente com seus roteiros não filmados. Para além desse legado estético de uma obra, o caso de O Sono sobre a Areia também revela como um roteiro é um potente índice de resgate e arquivo de processos históricos diluídos, apagados, e de futuras apropriações das suas proposições cinematográficas. Com esse roteiro, inclusive, torna-se possível rever as intenções de Mário Peixoto, a despeito dos acontecimentos engendrados por Carmen Santos.

O caso de O Sertanejo enseja uma série de procedimentos de visualização da história do cinema para além de uma história dos filmes que alcançaram as telas. Se toda leitura pública e dramática de um roteiro acena para uma potente imaginação histórica, 
despertada por um texto já tido como completo, O Sertanejo nos dá pistas de fortes anseios geracionais, estéticos e políticos, que faziam bastante sentido para quem estivesse diretamente envolvido com a indústria cinematográfica brasileira dos anos cinquenta. Como se fossem cenas possíveis de filmes não vistos, pois não filmados. Indo além de ser a ponta de iceberg de uma obra submersa, tal como acontece com a obra de roteiros não filmados de Mário Peixoto, casos como os de O Sertanejo e outros roteiros de Vitor Lima Barreto apontam para histórias que tiveram endosso, desejos, imaginários, repercussões e acontecimentos sociais bastante consistentes para o momento histórico preciso que poderiam ter deslindado. Nessa sismografia de acontecimentos históricos incompletos, nesses devires interrompidos, inerentes à arqueologia especulativa, é preciso reconhecer, por ora, que esses roteiros de Lima Barreto sedimentavam, em si, uma vontade de diálogo histórico entre gerações e tradições.

Por fim, os roteiros de Joaquim Pedro de Andrade sugerem uma importante síntese de duas vertentes estéticas distintas de sua obra, que não estão totalmente evidentes nos seus filmes realizados. Os vetores de um retrato íntimo e histórico-alegórico brasileiro, tidos como traços em Vida Mansa e Casa-Grande \& Senzala, culminam com raro vigor em O Impondrável Bento Contra o Crioulo Voador. Com esse roteiro, Joaquim Pedro de Andrade e Fernando Cony Campos inovam na representação de figuras militares, captam o imaginário da abertura e consolidam essa peculiar dialética entre os costumes, um imaginário íntimo e as alegorias da "grande história". Creio que esses roteiros auxiliam, inclusive, para uma reavaliação historiográfica do Cinema Novo, na sua faceta dos anos oitenta e sua revisão crítica aos seus períodos anteriores. Trata-se de uma obra que engendra vários estratos históricos, cuja interpretação no âmbito cinematográfico brasileiro ainda está por ser detalhada.

Somados e contrastados, os seis roteiros que analisamos neste ensaio permitem seguirmos mais adiante numa agenda ou possível contribuição dos roteiros não filmados dentro da historiografia do cinema brasileiro. Mais do que pensar em ciclos cinematográficos ou em linhas de coerência e outras periodizações, os roteiros não filmados gesticulam uma possível contribuição da (in)completude dentro da historiografia mais clássica do cinema brasileiro. Por esse viés, os roteiros não filmados conciliam obras autorais incompletas - sobretudo nos casos de Peixoto e Barreto, dadas suas escassas produções para as telas - como revela as forças e intenções estéticas dos seus cineastas ultrapassando as condições históricas e econômicas que faziam parte dos seus contextos. Roteiros não filmados revelam inquietações contracíclicas, que não sucumbiram aos 
"colapsos", às quedas ou, ainda, às linhas de coerência de e entre períodos. São forças caras às arqueologias especulativas, pois revelam acontecimentos tão incompletos como as cenas restritas às páginas, às suas fábulas e cenas sem telas ou aos olhos históricos.

Num contraste que subjaz a essas linhas conclusivas, é proveitoso comparar o papel que os roteiros não filmados possuem em cinematografias consolidadas ou com uma significativa produção permeada por um forte ritmo industrial. Na Hollywood clássica, como um primeiro parâmetro, embora haja muitos roteiros não filmados, os conjuntos de roteiros não filmados não é significativo o suficiente para vislumbrarmos outros rumos estéticos muito diferentes do que ocorreu nas telas. É possível, sim, entender melhor e com mais precisão, por exemplo, aspectos autorais de roteiristas importantes como Ben Hecht, Billy Wilder, Frances Marion e Herman Mankwiecz. Mesmo assim, esses roteiristas estavam inseridos num molde de trabalho tão frenético que conseguiram disseminar seus anseios, ideias e proposições estéticas num conjunto, muitas vezes, próximo da centena de filmes.

Num argumento econômico, os roteiros não filmados possibilitam apontamentos marginais da cinematografia Hollywoodiana. Em países "subdesenvolvidos", numa síntese que retoma a expressão de Salles Gomes, os roteiros não filmados teriam mais a dizer dos imaginários cinematográficos de sua época, da possível completude das obras de autores tidos como seminais, assim como de forças contracíclicas dos períodos que cada diretor-roteirista participou. Como arquivos históricos, os roteiros não filmados em contextos periféricos apontam para, especulações e arqueologias mais potentes e podem, com certeza, convergir vetores de futuras revisões historiográficas, dialogar e contribuir com as novas agendas de escritura de outras histórias do cinema brasileiro. Onde havia escassez, encontra-se abundância - focar nos roteiros não filmados, portanto, impele a compreender uma história do cinema que aposte em ultrapassar a hegemonia do paradigma da produção, e da recepção de público no seu tempo presente imediato. Uma forma de dar vista (parcial) a uma história que é tida como (integralmente) invisível.

\section{Referências}

ANDRADE, Joaquim Pedro. O imponderável Bento contra o crioulo voador. São Paulo: Marco Zero, 1990.

ANDRADE, Joaquim Pedro. Casa-Grande, Senzala \& Cia: Roteiro e Diário. Rio de Janeiro: Aeroplano, 2001.

ANDRADE, Joaquim Pedro. Vida Mansa. São Paulo: Arquivo Cinemateca Brasileira, 1980.

BERNARDET, Jean-Claude. Historiografia clássica do cinema brasileiro. São Paulo: Annablume, 2004. 
CALIL, Carlos Augusto. Posfácio. In: ANDRADE, Joaquim Pedro. O imponderável Bento contra o crioulo voador. São Paulo: Todavia, 2018.

CAVALCANTI, Alberto. Relatório geral sobre o cinema brasileiro. São Paulo: Arquivo da Cinemateca Brasileira, 1951.

GALVAO, Maria Rita. Burguesia e cinema: o caso Vera Cruz. Civilização Brasileira: São Paulo, 1981.

GONÇALO, Pablo. Uma Arqueologia especulativa: os roteiros não filmados de Mário Peixoto. Compós, 2018.

GOMES, Paulo Emílio Salles. Cinema: trajetória no subdesenvolvimento. Paz e Terra, São Paulo, 1996.

HARMAN, Graham. Speculative Realism: an Introduction. Cambridge: Polity Press, 2018.

\section{HEFFNER, Hernani. Contribuição a uma}

história do roteiro. Centro Cultural da Caixa Econômica Federal: Rio de Janeiro, 2012. p. 1143 (Catálogo da Mostra Leopoldo Serran).

LAWSON, John Howard: Theory and Technique of Playwriting. Hill and Wang Pub. 1960

MATTOS, Carlos Alberto: Walter Lima Jr: Viver Cinema. Rio de Janeiro: Casa da Palavra, 2002
MEILLASSOUX, Quentin. Après la Finitude:

Essais sur la nécessité de la contingence. Paris: Seuil Éditions, 2012.

MELLO, Luis Roberto Rocha. "Estouro na Praça": Alinor Azevedo, Alex Viany e a Comédia Musical Carioca. São Paulo: Caligrama, 2005. (v. 1).

PEIXOTO, Mário. A alma segundo salustre.

Rio de Janeiro: Embrafilme, 1983

PEIXOTO, Mário. O sono sobre a areia. Arquivo Mário Peixoto, Rio de Janeiro, 1931. PESSOA, Ana. Carmen Santos: o cinema dos anos 20. Rio de Janeiro: Editora Aeroplano, 2002.

PRICE, Steven. Screenplay: Authorship, Theory and Criticism. London: Palgrave Macmilian, 2003.

ROCHA, Glauber: Revisão crítica do cinema brasileiro. São Paulo: Cosac \& Naify, 2002. SOUZA, Carlos Roberto. Nossa aventura nas telas. São Paulo: Cultura Editores Associados, 1998.

XAVIER, Ismail. Sertão Mar: Glauber Rocha e a estética da fome. São Paulo: Cosac \&Naify, 2007.

WHITEHEAD, Alfred N. Process and Reality: an Essay in Cosmology. New York: Free Press, 1978.

\section{Informações sobre 0 artigo}

Resultado de projeto de pesquisa: 0 artigo é resultado da pesquisa de pós-doutorado intitulada Uma Arqueologia Especulativa: rastros dos roteiros não filmados na história do cinema, a qual foi realizada no programa de Pós-Graduação da Escola de Comunicação e Artes, ECA, na Universidade de São Paulo, no primeiro semestre de 2019. A pesquisa também contou com um levantamento de pesquisa e material na Cinemateca Brasileira, no Arquivo Mário Peixoto.

Fontes de financiamento: Não se aplica.

Considerações éticas: Não se aplica.

Declaração de conflito de interesses: Não se aplica.

Apresentação anterior: Não se aplica.

Agradecimentos/Contribuições adicionais: Agradecimentos a Eduardo Morettin, Ayla Pereira de Mello, Carlos Augusto Calil, Lila Foster, Fillippi Fernandes, Ismail Xavier, Hernani Heffner, Inácio Araújo, Carlos Roberto Souza, Marcos Napolitano, Denilson Lopes, Walter Lima Jr., aos colegas do Departamento de Audiovisual e Publicidade da UnB e do grupo de pesquisa História e Audiovisual: Circularidades e Formas de Comunicação. 


\section{Film dreaming: unfilmed scripts in Brazilian cinema}

\section{Abstract:}

The essay proposes a historiographical review of Brazilian cinema based on unfilmed scripts. Following an analysis of unfilmed scripts written by Mário Peixoto, Vítor Lima Barreto and Joaquim Pedro de Andrade the author suggests to understand styles, projects and aesthetic intentions that, though announced, were incomplete historical aspects in the cinematic cycles took part by these directors. These unfilmed scripts are analysed using a speculative archeology methodology. Whether in the cinema of the twenties, in the Vera Cruz project or in the relationship between Cinema Novo and Embrafilme, this set of scripts allow us to to glimpse counter-cycle aspects the cinematic periods that they had dialogued and promoted.

\section{Keywords:}

Brazilian Cinema. Film History. Unfilmed Scripts
Fábulas sin ojos: los guiones no filmados en la historiografía del cine brasileño

\section{Resumen:}

El ensayo propone una revisión historiográfica del cine brasileño basada en guiones no filmados. Después de un análisis de guiones no filmados por Mário Peixoto, Vítor Lima Barreto y Joaquim Pedro de Andrade, se sugiere capturar estilos, proyectos e intenciones estéticas que anunciaron aspectos históricos no consolidados en los ciclos cinematográficos comprendidos por estos directores. Estos guiones no filmados se analizan utilizando una metodología de arqueologia especulativa. Ya sea en el cine de los años veinte, en el proyecto Vera Cruz o en la relación entre Cinema Novo y Embrafilme, este conjunto de guiones revela poderosas imágenes estéticas que nos permiten vislumbrar aspectos anticíclicos de los periodos cinematográficos que dialogaron y presagiaron.

\section{Palabras clave:}

Cine brasileño. Historia del ine.

Guiones no filmados

\section{Pablo Gonçalo}

Doutor em Comunicação pelo Programa de Pós-Graduação em Comunicação da Universidade Federal do Rio de Janeiro, com passagem pela Universidade Livre de Berlim, quando foi bolsista do DAAD. Professor da Faculdade de Comunicação da Universidade de Brasília. Universidade de Brasília, Brasília, Distrito Federal, Brasil. E-mail: pablogoncalo@gmail.com 